\title{
A compact, fast UV photometer for measurement of ozone from research aircraft
}

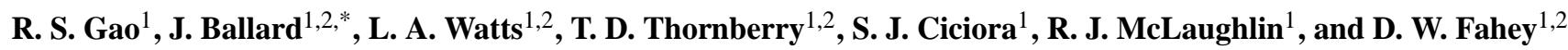 \\ ${ }^{1}$ National Oceanic and Atmospheric Administration, Earth System Research Laboratory, Chemical Sciences Division, \\ 325 Broadway, Boulder, Colorado, USA \\ ${ }^{2}$ Cooperative Institute for Research in Environmental Sciences, University of Colorado, Boulder, Colorado, USA \\ * now at: Zyvex Labs, Richardson, Texas, USA
}

Correspondence to: R. S. Gao (rushan.gao@noaa.gov)

Received: 5 April 2012 - Published in Atmos. Meas. Tech. Discuss.: 10 May 2012

Revised: 14 August 2012 - Accepted: 21 August 2012 - Published: 11 September 2012

\begin{abstract}
In situ measurements of atmospheric ozone $\left(\mathrm{O}_{3}\right)$ are performed routinely from many research aircraft platforms. The most common technique depends on the strong absorption of ultraviolet (UV) light by ozone. As atmospheric science advances to the widespread use of unmanned aircraft systems (UASs), there is an increasing requirement for minimizing instrument space, weight, and power while maintaining instrument accuracy, precision and time response. The design and use of a new, dual-beam, UV photometer instrument for in situ $\mathrm{O}_{3}$ measurements is described. A polarization optical-isolator configuration is utilized to fold the UV beam inside the absorption cells, yielding a 60$\mathrm{cm}$ absorption length with a $30-\mathrm{cm}$ cell. The instrument has a fast sampling rate $(2 \mathrm{~Hz}$ at $<200 \mathrm{hPa}, 1 \mathrm{~Hz}$ at $200-500 \mathrm{hPa}$, and $0.5 \mathrm{~Hz}$ at $\geq 500 \mathrm{hPa}$ ), high accuracy ( $3 \%$ excluding operation in the $300-450 \mathrm{hPa}$ range, where the accuracy may be degraded to about $5 \%)$, and excellent precision $\left(1.1 \times 10^{10}\right.$ $\mathrm{O}_{3}$ molecules $\mathrm{cm}^{-3}$ at $2 \mathrm{~Hz}$, which corresponds to $3.0 \mathrm{ppb}$ at $200 \mathrm{~K}$ and $100 \mathrm{hPa}$, or $0.41 \mathrm{ppb}$ at $273 \mathrm{~K}$ and $1013 \mathrm{hPa})$. The size (361), weight $(18 \mathrm{~kg})$, and power $(50-200 \mathrm{~W})$ make the instrument suitable for many UASs and other airborne platforms. Inlet and exhaust configurations are also described for ambient sampling in the troposphere and lower stratosphere $(1000-50 \mathrm{hPa})$ that control the sample flow rate to maximize time response while minimizing loss of precision due to induced turbulence in the sample cell. In-flight and laboratory intercomparisons with existing $\mathrm{O}_{3}$ instruments show that measurement accuracy is maintained in flight.
\end{abstract}

\section{Introduction}

Ozone is a key atmospheric trace gas that is produced and transported in both the troposphere and stratosphere and is present in mixing ratios ranging from parts per billion to parts per million. Ozone in the stratosphere protects the biosphere from harmful UV radiation from the sun and ozone in the free troposphere plays a major role in atmospheric oxidation. In the lower troposphere, ozone is a pollutant that is harmful to plants and ecosystems (e.g. Ashmore, 2005) and has negative impacts on human health (e.g. Mudway and Kelly, 2000).

A number of different techniques are commonly used for in situ $\mathrm{O}_{3}$ measurements in environmental research, including UV absorption (e.g. Bowman and Horak, 1974; Maier et al., 1978; Proffitt and McLaughlin, 1983), chemiluminescence (e.g. Regener, 1964; Aimedieu and Barat, 1981; Ridley et al., 1992), and electrochemistry (e.g. Brewer and Milford, 1960; Komhyr, 1969). Other techniques include photoacoustic (Veres et al., 2005) and chemical conversion plus cavity ring-down spectroscopy (Washenfelder et al., 2011). UV absorption is often chosen because of its absolute nature, overall simplicity, and reliability. Of particular merit is the lack of consumables required during operation, which makes UV absorption very suitable for continuous monitoring and long-endurance flights. A large number of UV $\mathrm{O}_{3}$ photometers have been developed and reported for airborne measurement of $\mathrm{O}_{3}$ including those described by Proffitt and McLaughlin (1983), Bognar and Birks (1996), Ross et al. (2000), Price et al. (2003), Mao et al. (2006), Brenninkmeijer et al. (2007), and Kalnajs and Avallone (2010). 
Ground level ozone concentrations are routinely monitored at sites worldwide using UV photometers.

In situ measurements of ozone are frequently made from airborne platforms, such as aircraft and balloons, in order to describe the ambient photochemical environment and the photochemical and dynamical history of sampled air. Observation of changes in ozone mixing ratio related to small-scale atmospheric structures, such as power plant and biomass burning plumes, convection, mixing of air parcels of different origins, and fine structure of stratospheric intrusions into the troposphere, requires measurements at high spatial resolution. With an aircraft as a measurement platform, spatial resolution is limited by instrument sampling rate. At the speeds of the jet-powered aircraft typically used for upper troposphere and lower stratosphere (UT/LS) studies, a measurement rate of $1 \mathrm{~Hz}$ corresponds to a horizontal spatial resolution of $100-200 \mathrm{~m}$. Vertical fluxes can be estimated using aircraft profiling measurements (Kort et al., 2012). Since the vertical gradients of atmospheric constituents cascade to scales less than $10 \mathrm{~m}$ (Lovejoy et al., 2007) and the ascent and descent rates of jet-powered research aircraft are on the order of $10 \mathrm{~m} \mathrm{~s}^{-1}$, sampling rates of $1 \mathrm{~Hz}$ or faster are highly desired. Many of the commercially available ozone photometers have measurement time constants ranging from several to $10 \mathrm{~s}$ of seconds, limiting the scale of phenomena that can be studied. Increasing the time resolution of measurements generally requires increasing some combination of instrument size, weight, and power consumption, which is undesirable given the constraints on aircraft payloads. Furthermore, with the expanding availability and use of unmanned aircraft system (UAS) platforms in atmospheric research, there is an increased need for airborne instruments that are lighter, smaller, and require less power to operate, while maintaining the performance specifications of larger contemporary instruments.

We describe a new ozone UV photometer, designated here as NOAA- $2 \mathrm{O}_{3}$, specifically built for use on high- and lowaltitude research aircraft. The new photometer was successfully operated on board two research aircraft, the NASA Global Hawk UAS and the NASA WB-57F high-altitude aircraft. The new instrument represents an example of how size, weight, and power can be reduced without loss of instrument performance. The following sections describe the instrument and sampling inlet designs along with performance results from laboratory and flight testing. The instrument performance tests include intercomparisons with a previously built NOAA ozone instrument, described by Proffitt and McLaughlin (1983) and designated here as NOAA-1 $\mathrm{O}_{3}$. This instrument has flown on hundreds of flights on board the NASA ER-2 and other high-altitude research aircraft since 1985.

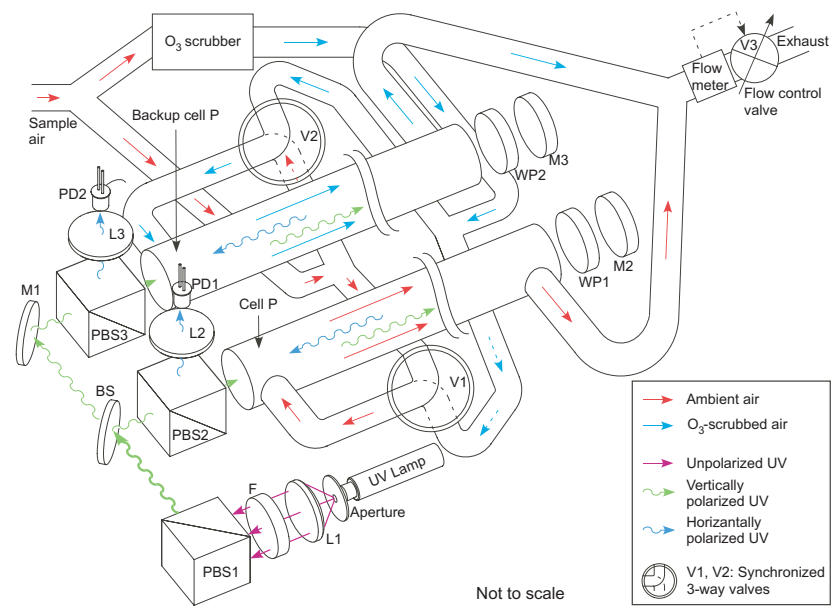

Fig. 1. Schematic of the new NOAA-2 $\mathrm{O}_{3}$ instrument showing the configuration of the key optical and air flow components: Ln: lens; F: UV filter; PBSn: polarizing beam splitter; BS: polka-dot 50-50 beam splitter; Mn: mirror; WPn: quarter-wave plate; PDn: silicon photodiode detector; V1 and V2: synchronized 3-way flow-control valves; V3: flow-control valve. Schematic is not to scale. The legend indicates how the polarizations of the UV beams, and scrubbed and unscrubbed sample air are illustrated.

\section{Instrument description}

\subsection{General description}

The NOAA-2 $\mathrm{O}_{3}$ photometer design illustrated in Fig. 1 is a derivative of the dual-beam, unpolarized, UV absorption technique described by Proffitt and McLaughlin (1983). Briefly, ambient and $\mathrm{O}_{3}$-scrubbed airflows are alternately directed into two identical absorption cells. 253.7-nm UV light from a mercury lamp is split into two beams that are each directed into one of the absorption cells. Since $\mathrm{O}_{3}$ strongly absorbs photons at $253.7 \mathrm{~nm}$, the UV beam passing through the cell containing ambient ozone is attenuated more than the beam passing through the cell containing $\mathrm{O}_{3}$-scrubbed air. Knowing the $\mathrm{O}_{3}$ absorption cross section $(\sigma)$ and the absorption path length $(L)$, the $\mathrm{O}_{3}$ partial pressure $\left(p_{\mathrm{O}_{3}}\right)$ can be derived using Beer's law. For a given optical system, the instrument precision generally improves with increasing $L$. For photometers designed for airborne measurements, $L$ is typically $40 \mathrm{~cm}$ or less, and is limited in part by the allowable instrument overall dimensions.

\subsection{Optical configuration}

In the new photometer design, a novel optical system was developed (see Fig. 1) that folds the UV beam inside the absorption cells and, thereby, doubles the absorption path length for a given physical cell length. A polarization opticalisolator configuration is utilized to fold the UV beam inside the $1.6 \mathrm{~cm}$ ID Teflon-lined aluminum absorption cells, yielding a $60-\mathrm{cm}$ absorption length within the $30-\mathrm{cm}$ long cells. In 


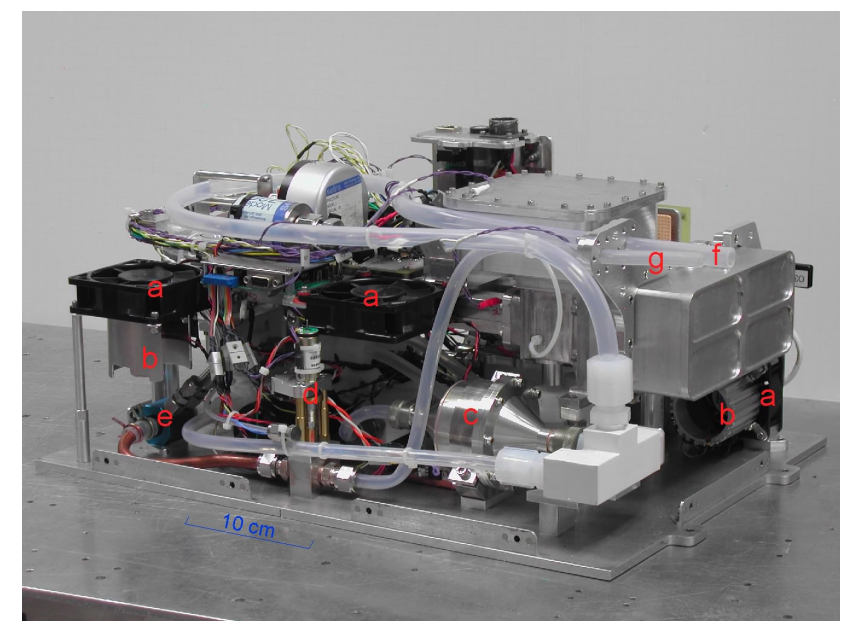

Fig. 2. A photo of the NOAA-2 $\mathrm{O}_{3}$ instrument without its enclosure showing (a): fans; (b): heaters; (c): catalytic scrubber; (d): flow control valve (V3); (e): sample flow sensor; (f): sample line; (g): exhaust line.

this configuration, the unpolarized output of a mercury lamp (see Sect. 2.3) is collimated by a lens and passes through a 254-nm bandpass filter before being vertically polarized by a polarizing beam splitter (PBS1). The resulting polarized beam is then split into two beams using a non-polarizing polka-dot beam splitter (BS) and mirror (M1) combination, with half of the light entering each of two absorption cells unimpeded through a polarizing beam splitter (PBS2 and PBS3, respectively). On the distal end of each cell, the light is reflected and the polarization rotated by $90^{\circ}$ using a precision quarter-wave plate and mirror combination (WP1, M2 and WP2, M3). After the return pass through the absorption cells, the now horizontally polarized light is reflected upward into a silicon photodiode by entrance polarizing beam splitter (PBS2 and PBS3). The optical path length in the NOAA-1 $\mathrm{O}_{3}$ instrument is the physical cell length of $40 \mathrm{~cm}$.

A reduced cell length reduces the required physical size of the instrument for a given precision. In addition, the shorter cell of this double-pass design has the advantage of a shorter sample-air residence time inside the cells, which increases the allowable sampling rate for a given sample flow. Furthermore, the folded optical path allows an optimally compact design by locating all the significant optical and electronic components on only one end of the cell. The new instrument specifications are listed in Table 1. A photo of the instrument without its flight enclosure is shown in Fig. 2.

\subsection{UV lamp}

The NOAA- $1 \mathrm{O}_{3}$ instrument uses a Pen-Ray mercury lamp (UVP, LLC Upland, CA). In the NOAA-2 $\mathrm{O}_{3}$ instrument, linearly polarizing the UV beam from the lamp reduces by one half the UV flux available in each absorption cell. As a consequence of the use of polarized beams and an increase in $L(60 \mathrm{~cm}$ vs. $40 \mathrm{~cm})$, the Pen-Ray lamp does not provide sufficient photon flux to achieve a similar detection limit. Instead, the new instrument uses a capillary mercury lamp (Jelight Company, Inc., Irvine, CA, Part No. 3CPG-1). An aperture $(d \sim 0.5 \mathrm{~mm})$ blocks stray light, creating an effective UV point source. With a custom power supply, this lamp consumes approximately $6 \mathrm{~W}$ of power and provides a useable photon flux over 1 order of magnitude greater than the Pen-Ray lamp.

\subsection{Sample flow control}

The NOAA-2 $\mathrm{O}_{3}$ instrument does not use active pumping to pull sample air through the absorption cells. Instead, ram pressure (about $20-40 \mathrm{hPa}$ ) at the sampling inlet opening created by the aircraft movement at $100-200 \mathrm{~m} \mathrm{~s}^{-1}$ pushes ambient air through the instrument from the inlet opening to the exhaust opening. As shown in Fig. 1, the inlet flow is split with half passing through an $\mathrm{O}_{3}$ scrubber unit and half remaining unscrubbed. Three-way valves (V1 and V2) serve to alternate the scrubbed and unscrubbed flows in each absorption cell every $10 \mathrm{~s}$.

The flows exiting the absorption cells are merged into a common exhaust line. A volumetric flow meter (Pneumotachograph Type 0, Phipps and Bird Fleisch, Richmond, VA) is used for measuring the total merged flow downstream of the absorption cells. Flow regulation is achieved using a custom butterfly vane valve (V3) with an ID of $9.53 \mathrm{~mm}$ based on the design by Gao et al. (1999)

For an instrument with an emphasis on high precision and fast time response, careful flow control is very important. Sufficient flow is needed to ensure the time required to completely flush the absorption cell volume is the same or shorter than the time between successive reported measurement intervals. Otherwise, the time resolution of the instrument will be less than the reported measurement interval. On the other hand, if the sample flow is too fast, excessive air turbulence may cause noise in the optical detector signals, thereby degrading the instrument precision. The challenge is to design a sample flow system that avoids these two issues for the desired measurement interval.

The effective flushing period is determined by the time required to interchange the scrubbed and unscrubbed flows between absorption cells. With an internal cell volume of about $84 \mathrm{~cm}^{3}$, the total volume between the 3-way flow switching valves (V1 and V2) and the cell exhaust points is approximately $190 \mathrm{~cm}^{3}$. Assuming plug flow, the minimum volume flow rate for a flush time of $0.5 \mathrm{~s}$ is about 22 liters per minute (LPM). In practice, a 27 LPM flow rate is needed to ensure a $0.5 \mathrm{~s}$ flush rate needed for true $2 \mathrm{~Hz}$ measurements. One data point immediately after the valves V1 and V2 switch is discarded (Proffitt and McLaughlin, 1983). The sampling rate of $2 \mathrm{~Hz}$ of the NOAA- $2 \mathrm{O}_{3}$ corresponds to a horizontal resolution of $100-200 \mathrm{~m}$ and a vertical resolution of $5 \mathrm{~m}$ or less, respectively, at typical research speeds. 
Table 1. Specifications of the $\mathrm{NOAA} \mathrm{O}_{3}$ instruments.

\begin{tabular}{|c|c|c|}
\hline Parameter & New NOAA-2 $\mathrm{O}_{3}$ instrument & NOAA-1 $\mathrm{O}_{3}$ instrument \\
\hline Sampling rate & $2 \mathrm{~Hz}$ & $1 \mathrm{~Hz}$ \\
\hline Accuracy & $3 \%$ & $3 \%$ \\
\hline Precision with sample flow & $1.1 \times 10^{10} \mathrm{O}_{3}$ molecules $\mathrm{cm}^{-3}$ & $1.5 \times 10^{10}$ molecules $\mathrm{cm}^{-3}$ \\
\hline Size & $48 \mathrm{~cm} \times 34 \mathrm{~cm} \times 22 \mathrm{~cm}$ & $76 \mathrm{~cm} \times 46 \mathrm{~cm} \times 18 \mathrm{~cm}$ \\
\hline Weight & $18 \mathrm{~kg}$ & $26 \mathrm{~kg}$ \\
\hline Power (28 VDC) & $\sim 200 \mathrm{~W}$ (peak) ${ }^{\mathrm{a}} ; \sim 50 \mathrm{~W}($ normal) & $\sim 200 \mathrm{~W}$ (peak) ${ }^{\mathrm{a}} ; \sim 50 \mathrm{~W}($ normal $)$ \\
\hline
\end{tabular}

a A large portion of power is used for achieving (peak) and maintaining (normal) an adequate internal temperature during an aircraft flight in the UT/LS. The normal power consumption depends strongly on the instrument ambient temperature conditions.
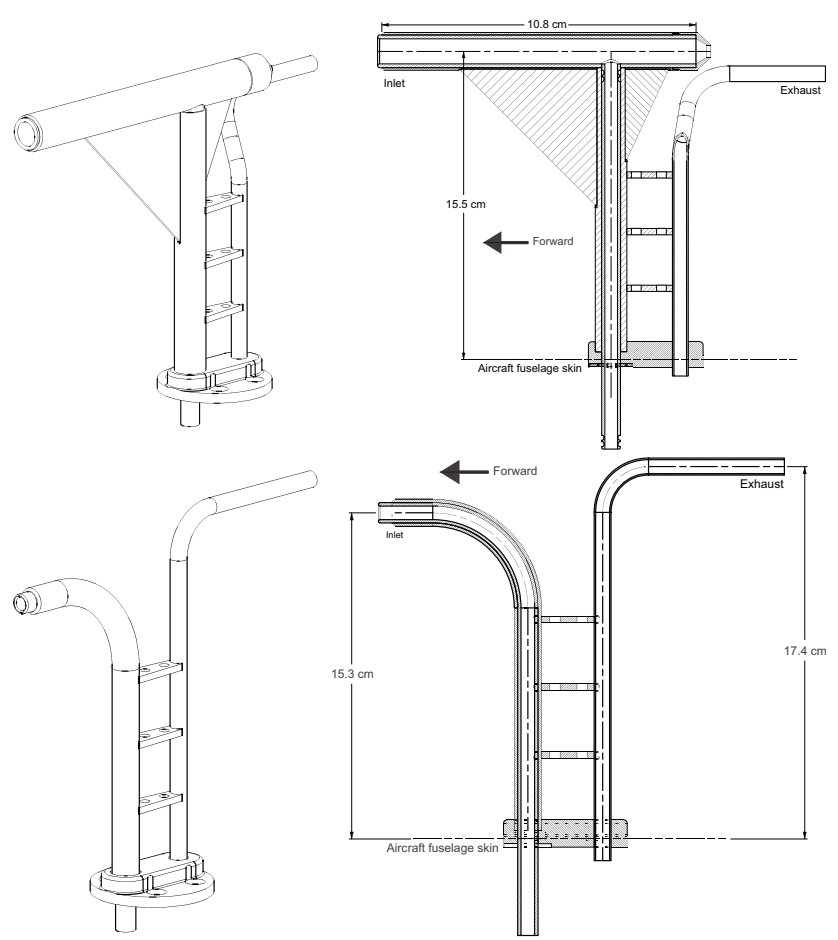

Fig. 3. Two types of NOAA-2 $\mathrm{O}_{3}$ inlets tested on board the NASA WB-57F aircraft. Upper panel: side-facing inlet with a tubular scoop. Lower panel: simple forward-facing inlet. Drawing is shown to scale.

\subsection{Sample inlets}

Figure 3 shows two different passive inlet/exhaust configurations used in flight tests of the new instrument. The inlet configuration shown in the upper panel is a side-facing inlet with a forward-facing tubular scoop that is a Teflon ${ }^{\circledR}$-lined tube with a $1.3-\mathrm{cm}$ internal diameter (ID) inlet opening and a smaller restricted exit opening (0.64-cm ID). The restriction at the exit port raises air pressure inside the inlet tube and pushes air into the side-facing sample line (Teflon ${ }^{\circledR}$ PFA tubing, $0.95-\mathrm{cm}$ OD, $0.64 \mathrm{~cm} \mathrm{ID)}$. The lower panel shows a simpler forward-facing inlet configuration made of stainless steel $(1.27-\mathrm{cm}$ outside diameter (OD), 0.953-cm ID) lined with a Teflon ${ }^{\circledR}$ PFA tubing (0.95-cm OD, 0.64-cm ID). Sample exhaust openings for both configurations are at the ends of backward-facing stainless steel tubes $(0.80-\mathrm{cm}$ OD, $0.64-$ $\mathrm{cm}$ ID stainless steel). Both configurations require mechanical strength and rigidity to withstand drag stresses during flight.

A passive inlet requires a forward-facing inlet opening to realize ram pressure. In some cases, the exhaust opening can also provide pumping to increase the pressure differential across the instrument. The advantage of the configuration in the top panel of Fig. 3 is that debris such as dirt, insects or hydrometeors with sufficient inertia are prevented from turning the corner and entering the sample line to the instrument. This keeps the instrument cell windows and walls clean, thus maintaining instrument performance. The disadvantage of this configuration is that it is more prone to cause turbulence in the sample line that persists into the absorption cells. This turbulence causes fluctuations in the index of refraction of air in the cells, which scatters the UV light (Booker and Gordon, 1950; Munick, 1965) and leads to a slight degradation of instrument precision.

\subsection{Catalytic ozone scrubber}

As shown in Fig. 1, the sample flow is split into two, and one of the flows passes through the $\mathrm{O}_{3}$ scrubber unit before entering one of the absorption cells. The unit shown in Fig. 4 was specifically designed and constructed to catalytically destroy $\mathrm{O}_{3}$ in the flow, while not causing a significant pressure drop compared a sample line of the same length. A large pressure drop can lead to unbalanced flows in the two absorption cells, and therefore degraded instrument time resolution. As shown, the sample air stream entering the scrubber is expanded and slowed to increase reaction time. Brass membranes containing a variety of holes are located at the entrance and exit to ensure near plug flow of the sample air inside the scrubber. Catalytic reactions occur on a total of 20 manganese oxide screens, taken from commercial catalysts (www.thermoscientific.com, Part \#14697) that are stacked uniformly in the middle of the scrubber volume. The exposed screen diameter is $51 \mathrm{~mm}$. The scrubber unit was tested by passing air with $6 \mathrm{ppm} \mathrm{O}_{3}$ through it at $14 \mathrm{LPM}$ 


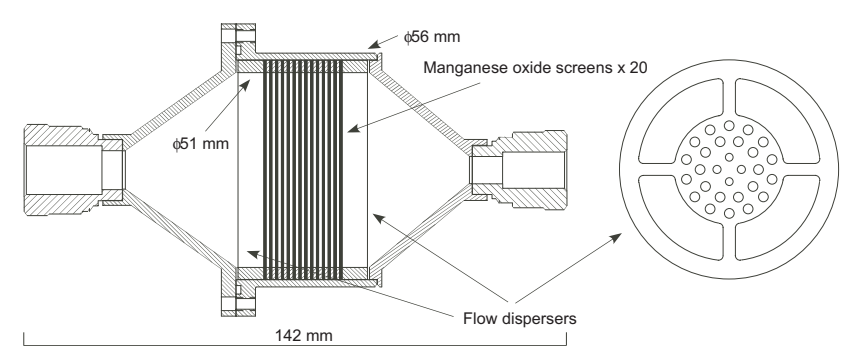

Fig. 4. Cross-sectional view of the catalytic $\mathrm{O}_{3}$ scrubber (left) and flow disperser (right). The exposed manganese oxide screen diameter is $51 \mathrm{~mm}$. The schematic is shown to scale.

at pressures down to $50 \mathrm{hPa}$. The output of the scrubber was sampled with the NOAA- $2 \mathrm{O}_{3}$, which showed no measurable $\mathrm{O}_{3}(<0.5 \mathrm{ppb})$ for several hours of operation.

\subsection{Temperature control}

$\mathrm{O}_{3}$ artifacts can also be caused by temperature gradients along or between the absorption cells. To ensure the best performance, the entire volume of the instrument is temperature controlled. As shown in Fig. 2, two 50-W heaters are mounted on aluminum heat exchangers placed directly in front of two of three circulation fans inside the instrument flight enclosure (not shown). The circulation warms and cools components to achieve a uniform operating temperature. Temperature controllers using sensors placed upstream of the fans control enclosure air temperatures to $300 \pm 1 \mathrm{~K}$, or $\pm 0.3 \%$. A 1 -mm thick aluminum enclosure serves as a thermal barrier from ambient temperatures that vary depending on the location of the instrument. When the instrument is used in unheated and unpressurized aircraft payload locations, a 3-mm thick Nomex insulation felt lines the inside surfaces of the enclosure as additional thermal insulation. Sample air is heated before entering the absorption cells as it flows through an $80-\mathrm{cm}$ segment of Teflon ${ }^{\circledR}$ tubing (11.4-mm OD) located inside the enclosure on top of instrument in Fig. 2.

\subsection{Cell pressure}

Absorption cell pressure is needed to calculate the $\mathrm{O}_{3}$ mixing ratio from $\mathrm{O}_{3}$ partial pressure. During a flight, the cell pressure fluctuates in response to changes in ambient pressure. An accurate measurement of the cell pressure is therefore critical for accurate and precise $\mathrm{O}_{3}$ mixing ratio data. The pressure sensor chosen must be independent of ambient pressure in the payload location. An Esterline 78005001A (Esterline Advanced Sensors, Farnborough, England) vibratingcylinder pressure sensor was used based on its excellent stability, accuracy, precision, temperature compensation, and the lack of sensitivity to ambient pressure changes. Frequent intercomparisions with NOAA laboratory standards showed that its measurements were stable and accurate over $2 \mathrm{yr}$ to approximately $\pm 0.5 \mathrm{hPa}$, or $< \pm 1 \%$.

The difference in pressure between the two absorption cells is small under flight conditions $(<0.1 \mathrm{hPa})$. Therefore, only one pressure sensor is needed for cell pressure measurements. A Setra Model 720 pressure sensor (Setra Systems, Inc., Boxborough, MA) is used in parallel to the Esterline pressure transducer as a backup sensor and to provide a diagnostic for stability of the primary pressure measurement.

\subsection{Data system}

A National Instruments CompactRIO controller (National Instruments, Austin, TX) was used for instrument control, data collection, and communication with the host aircraft. A detailed description of the data system can be found at http://sine.ni.com/cs/app/doc/p/id/cs-12343.

\section{Instrument performance}

The instrument performs well in the laboratory and in flight. The optical system is very robust, unaffected by in-flight vibrations. No problems due to imperfect polarization or misalignment were experienced. This is not unexpected since imperfect polarization or misalignment only affect instrument baseline signal strength, while the data reduction algorithm is only sensitive to the short-term changes in signal due to valve switching, which are, of course, due to $\mathrm{O}_{3}$ changes (Proffitt and McLaughlin, 1983).

\subsection{Precision}

Since the NOAA- $2 \mathrm{O}_{3}$ instrument measures the $\mathrm{O}_{3}$ molecular density, the instrument precision is expressed in units of molecules $\mathrm{cm}^{-3}$. The intrinsic instrument precision is determined by noise in the optical system, signal digitizer, and pressure and temperature sensors. The intrinsic precision was determined using data recorded with no sample flow through the instrument. As shown in Fig. 5, the typical value of the intrinsic precision is about $5 \times 10^{9}$ molecule $\mathrm{cm}^{-3}$ (equivalent to $1.4 \mathrm{ppb}$ at $200 \mathrm{~K}$ and $100 \mathrm{hPa}$, or $0.19 \mathrm{ppb}$ at $273 \mathrm{~K}$ and $1013 \mathrm{hPa}$ ).

With a folded light path, the $\mathrm{O}_{3}$ partial pressure measurement is twice as sensitive to sample flow turbulence as a single-path configuration. To optimize instrument performance, flow-induced noise was recorded as a function of pressure and volume flow rate of the sample air. Figure 6 shows a typical measurement at a fixed flow rate of 20 LPM. Based on these measurements, the flow controller was programmed to control the sample flow in flight at 27 LPM for cell pressure $<200 \mathrm{hPa}, 15 \mathrm{LPM}$ with $200 \leq$ cell pressure $<$ $500 \mathrm{hPa}$, and $10 \mathrm{LPM}$ with cell pressure $\geq 500 \mathrm{hPa}$. At these flow rates, the flow-induced noise is always smaller than the intrinsic precision measured with no flow. Note that at flow rates of 15 and $10 \mathrm{LPM}$, the minimum $\mathrm{O}_{3}$ measurement time 


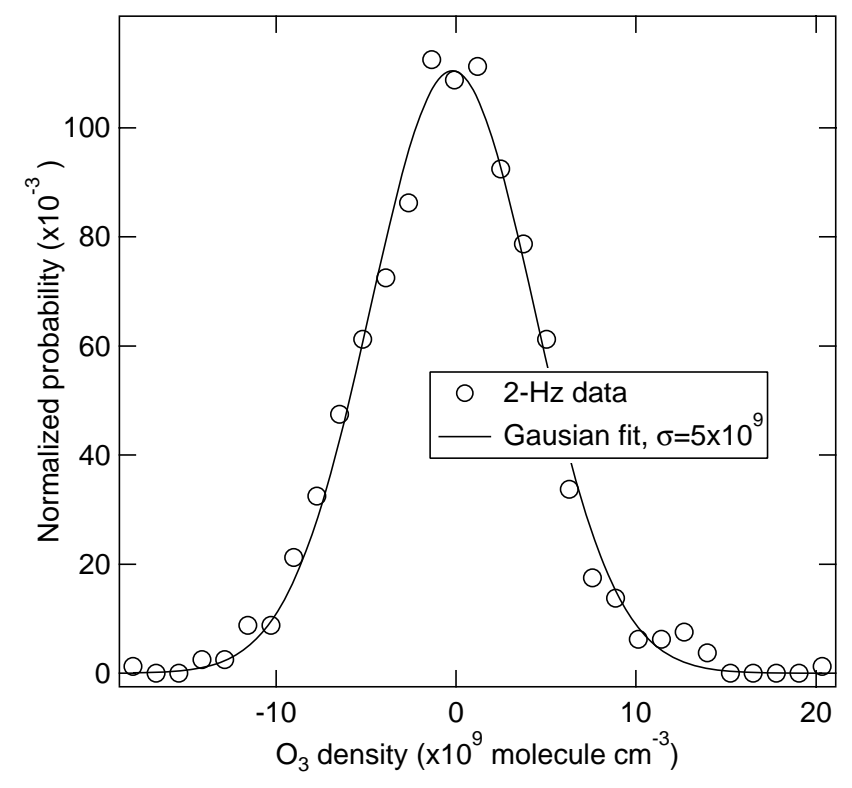

Fig. 5. A typical determination of the intrinsic instrument precision of NOAA- $2 \mathrm{O}_{3}$ instrument. $\mathrm{O}_{3}$ measurements recorded for a $1000-\mathrm{s}$ period at $2 \mathrm{~Hz}$ without sample flow were used to form a probability distribution function (PDF). The PDF integral is normalized to 1. As shown, the distribution of the data is very close to a perfect Gaussian, indicating that the measurement noise is random. The Gaussian fit gives a precision $(2 \mathrm{~Hz}, 1 \sigma)$ of $5 \times 10^{9}$ molecule $\mathrm{cm}^{-3}$.

resolution lengthens to approximately $1 \mathrm{~s}$ and $2 \mathrm{~s}$, respectively. Due to the increased flush time at lower flow rates, the number of data points discarded immediately after V1 and V2 switches is increased from one to two and four for 15 LPM and 10 LPM, respectively (cf. the last paragraph of Sect. 2.4).

For atmospheric sampling, additional noise generally arises from pressure fluctuations related to the sample inlet configuration and aircraft electronic interference. An upper limit of in-flight precision can be determined by examining measurement statistics in 250-s flight segments with low $\mathrm{O}_{3}$ variability. As an example, data collected onboard the NASA Global Hawk UAS with the simple forward-facing inlet (Fig. 3, lower panel), an ambient pressure of $110 \mathrm{hPa}$ and a sample flow near 27 LPM yielded an in-flight $1-\sigma$ precision of approximately $1.1 \times 10^{10}$ molecule $\mathrm{cm}^{-3}$ (equivalent to $3.0 \mathrm{ppb}$ at $200 \mathrm{~K}$ and $100 \mathrm{hPa}$, or $0.41 \mathrm{ppb}$ at $273 \mathrm{~K}$ and $1013 \mathrm{hPa}$ ) or approximately twice the intrinsic precision.

The precision can be greatly affected by the inlet configuration. On board the Global Hawk UAS with the inlet configuration using the side-facing Teflon ${ }^{\circledR}$-lined tube (Fig. 3, upper panel), an ambient pressure of $80 \mathrm{hPa}$ and a sample flow near 25 LPM yielded an in-flight $1-\sigma$ precision of approximately $1.9 \times 10^{10}$ molecule $\mathrm{cm}^{-3}$ or approximately four times the intrinsic precision. The additional noise is attributed to small sub-Hertz oscillations in the $\mathrm{O}_{3}$ partial pressure values.

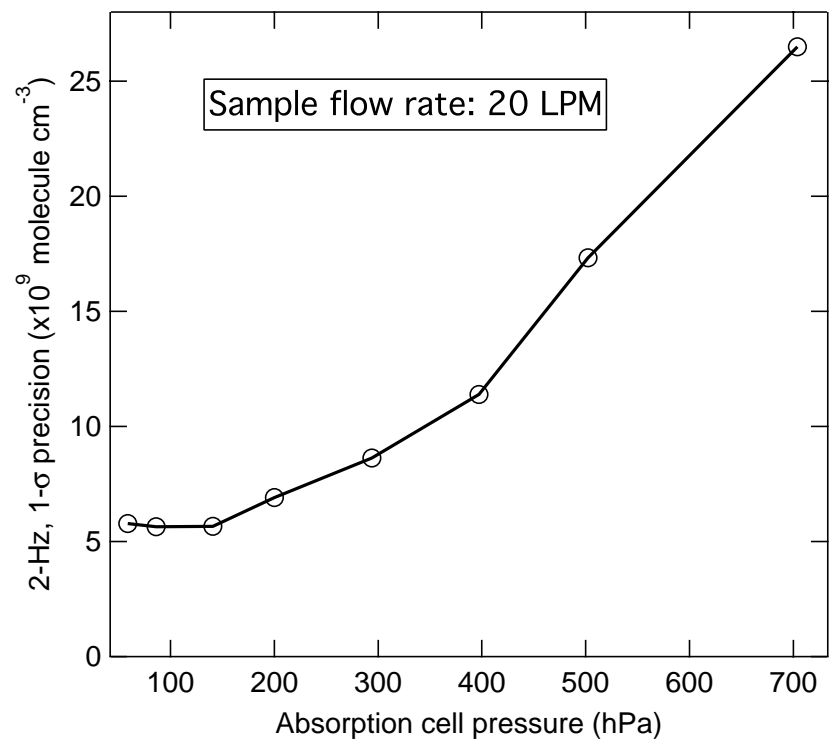

Fig. 6. NOAA-2 $\mathrm{O}_{3}$ instrument precision $(2 \mathrm{~Hz}, 1 \sigma)$ as a function of absorption cell pressure at a fixed sample volume flow of 20 LPM. The intrinsic instrument precision (no flow) is $5 \times 10^{9}$ molecule $\mathrm{cm}^{-3}$.

\subsection{Laboratory accuracy}

Since the NOAA-2 $\mathrm{O}_{3}$ instrument is based on the same principles described by Proffitt and McLaughlin (1983) (see also Zucco et al., 2003), their detailed error analysis can be directly applied here. Briefly, the largest error sources are absorption length, $\mathrm{O}_{3}$ absorption cross section at $253.7 \mathrm{~nm}$ (see, e.g. Barnes and Mauersberger, 1987; Sander et al., 2011), pressure and temperature of sample air inside absorption cells, and $\mathrm{O}_{3}$ loss to the wall material. In our new instrument, a high quality pressure sensor and good overall temperature control ensure the temperature and pressure errors are well less than $1 \%$. Temperatures measured at several positions inside the instrument vary within $\pm 1 \mathrm{~K}$ of $300 \mathrm{~K}$, or about $\pm 0.4 \%$, during flight. Uncertainty in the absorption cross section due to temperature variation is negligible (Barnes and Mauersberger, 1987). An all-Teflon ${ }^{\circledR}$ wetted surface construction and fast sample flow prevent measurable ambient $\mathrm{O}_{3}$ loss inside the instrument. Error in determination of the absorption cell length is also less than $1 \%(3 \mathrm{~mm})$. The resulting overall accuracy is $\pm 3 \%$, the same as given by Proffitt and McLaughlin (1983) without consideration of wall loss.

As a further assessment of accuracy, the NOAA-2 $\mathrm{O}_{3}$ instrument was intercompared in the laboratory with the NOAA-1 $\mathrm{O}_{3}$ instrument and a commercial primary standard (Model 49i-PS, Thermo Electron Corporation (TECO), Franklin, MA). All of these instruments are based on the same UV absorption technique. The TECO $\mathrm{O}_{3}$ instrument has an accuracy specification of $\pm 1-2 \%$. It is treated at NOAA as a primary standard using sample flows that are 


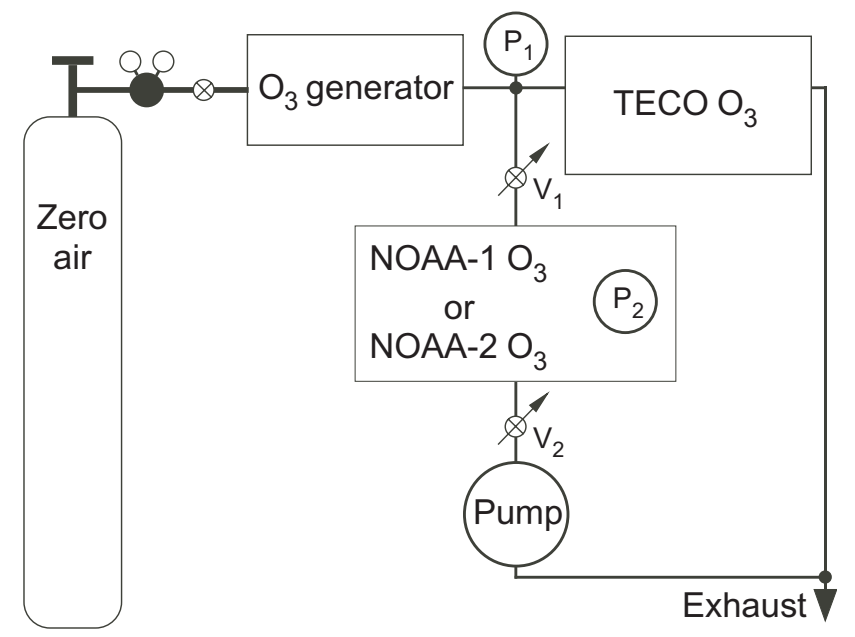

Fig. 7. Laboratory setup for the $\mathrm{O}_{3}$ instrument intercomparison. Gas lines between the $\mathrm{O}_{3}$ generator and $\mathrm{O}_{3}$ instruments and valve $\mathrm{V} 1$ are made of PFA Teflon ${ }^{\circledR}$. V1 is used to ensure that pressure $P_{1}$ is always above laboratory ambient pressure. V2 is used to control the pressure inside the NOAA-1 or NOAA- $2 \mathrm{O}_{3}$ instruments undergoing an intercomparison with the TECO Model 49i-PS primary standard instrument.

restricted to dry synthetic air. The laboratory setup for intercomparing two instruments is shown in Fig. 7. The typical set of results for the NOAA- $2 \mathrm{O}_{3}$ and the TECO instruments in Fig. 8 shows that the instruments agree well with each other with the correlation slope being 1.01 over a wide cellpressure range. A similar slope is found with another TECO instrument and with the NOAA- $1 \mathrm{O}_{3}$ instrument, indicating that the NOAA-2 $\mathrm{O}_{3}$ has a systematic positive bias of $1 \%$ with respect to the TECO primary reference measurement. Although the cause of this bias is unknown, the NOAA- $2 \mathrm{O}_{3}$ atmospheric measurements are adjusted downward by $1 \%$ to be consistent with the other three instruments.

In conducting the intercomparison, care was taken to ensure that instrument leaks did not influence the outcome. Since many parts, such as the flow switching valves and absorption cells, are made of Teflon ${ }^{\circledR}$, leaks are always a potential threat to the $\mathrm{O}_{3}$ measurements. Both NOAA-1 and NOAA-2 $\mathrm{O}_{3}$ instruments are designed for aircraft operation in pressurized or unpressurized payload areas. In the latter, leaks are generally not an issue, whereas large leaks in a pressurized environment could potentially alter the $\mathrm{O}_{3}$ measurements. We note that a leak of air with less $\mathrm{O}_{3}$ than in the sample air occurring into one of the absorption cells or further upstream would result in a negative bias in the measurement. Leaks further downstream do not affect the measurements. To ensure no leaks are large enough to affect the measurements, we routinely run the NOAA- 1 and NOAA- $2 \mathrm{O}_{3}$ instruments at a range of sample pressures using the laboratory setup shown in Fig. 7. As shown, the sample pressure $\left(P_{1}\right)$ for the TECO $\mathrm{O}_{3}$ is always at a pressure slightly above ambient

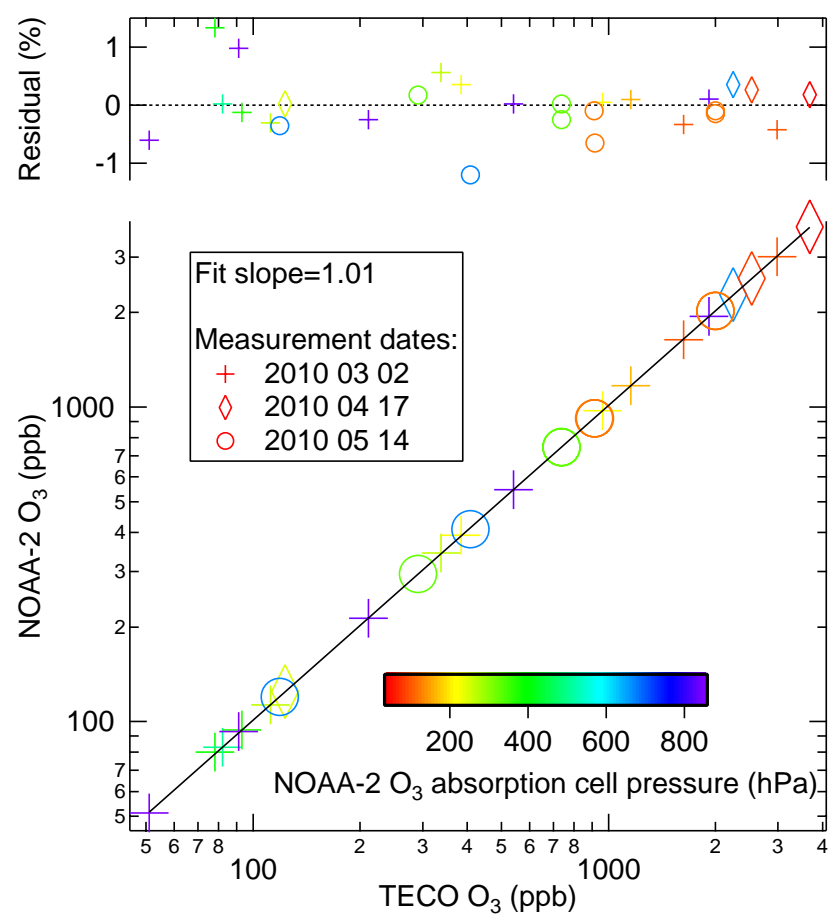

Fig. 8. Intercomparison between the NOAA-2 $\mathrm{O}_{3}$ and the TECO $\mathrm{O}_{3}$ primary standard instrument over a range of cell pressures in the NOAA-2 $\mathrm{O}_{3}$ instrument. Each data point represents a 40-s average of $\mathrm{O}_{3}$ mixing ratio in units of parts per billion (ppb). The slope of the linear best fit through the origin is $1.01 \pm 0.01$. The fit residuals are shown in the top panel.

pressure. Partial control of $P_{1}$ is provided by the all-Teflon ${ }^{\circledR}$ valve, V1. An above-ambient value of $P_{1}$ ensures that no leaks can occur into the TECO instrument and cause errors in the measurements. The pressure in the NOAA instruments being compared is controlled by a second valve, V2, and a vacuum pump. If there is no significant leak in the NOAA instruments, then the results of the comparison should be independent of $P_{2}$, as demonstrated in Fig. 8. It is noted that the scatter in Fig. 8, upper panel, is larger than the combined precisions of the two instruments. We attribute this increased scatter to the unregulated nature of the $\mathrm{O}_{3}$ generation.

\subsection{Humidity artifact}

A negative artifact (i.e. measured values are lower than actual ones) has been observed under some conditions when the sample humidity abruptly changes from wet to dry (Meyer et al., 1991; Kleindienst et al., 1993; Wilson and Birks, 2006). This artifact appears to be related to water on the cell walls and optical elements affecting the transmission of the unfocused UV beam. When the humidity is abruptly reduced, desorption of water from the catalyst creates an imbalance in cell humidity and, thereby, an artifact response. This desorption and artifact response will in general be strongly dependent on the composition and surface area of the catalyst material (and 
possibly cell optical components). For the catalyst and optical components used in both $\mathrm{NOAA} \mathrm{O}_{3}$ instruments, this artifact is small under normal flight conditions ( $\sim 30 \mathrm{~min}$ from wet lower troposphere to dry upper troposphere). To examine the potential magnitude of the artifact, tests have been conducted by replacing $\mathrm{O}_{3}$-scrubbed ambient air $(\sim 1 \%$ water $)$ with dry synthetic air (<10vppm water) within a couple seconds. Both instruments exhibited a negative bias of $<10 \mathrm{ppb}$ at $820 \mathrm{hPa}$ that drops to $\sim 2 \mathrm{ppb}$ after $6 \mathrm{~min}$ and continuously decreases to $\sim 0.2 \mathrm{ppb}$ over a period of $30 \mathrm{~min}$. This artifact is mostly pressure independent and, therefore, is relatively more important at lower absorption cell pressures and lower $\mathrm{O}_{3}$ values. An important feature of the NOAA instruments is that the water artifact diminishes when $\mathrm{O}_{3}$ is present in the dry air after the humidity change in the sample flow. Specifically, when the $\mathrm{O}_{3}$ density level is above about $130 \mathrm{ppb}$ at $\sim 125 \mathrm{hPa}$, the artifact is completely unobservable. This feature, together with the relatively fast decay of the artifact, means that on an aircraft ascending quickly from near sea level to the upper troposphere or flying out of a high humidity in a cloud, the NOAA instruments will likely not suffer a significant $\mathrm{O}_{3}$ artifact.

A positive measurement artifact could potentially occur following a sudden increase in humidity. However, due to the rapid equilibration of catalyst surfaces to increases in water, this artifact is much less severe compared to the negative artifact and was found to be negligible in NOAA-1 and NOAA-2.

\subsection{Field intercomparison}

In March and April 2011, the NOAA-1 and NOAA-2 $\mathrm{O}_{3}$ instruments flew together on board the NASA WB-57F aircraft based in Houston, TX as part of the NASA Mid-latitude Airborne Cirrus Properties Experiment (MACPEX) mission. The aircraft extensively sampled the UT/LS at altitudes up to $18 \mathrm{~km}$, with $\mathrm{O}_{3}$ mixing ratios reaching values of about $1 \mathrm{ppm}$. Data from a typical flight are shown in Fig. 9. The agreement between the two instruments is within $1 \%$ except in the pressure range of $300-450 \mathrm{hPa}$, where the difference is on the order of $5 \%$. The probability distribution of the differences between the two instruments is shown in Fig. 9, lower panel. A double-Gaussian function fits the data well, with one Gaussian peak at $-1 \%$ (with NOAA-1 being lower) with a width of $3 \%$, and the other Gaussian peak at $+5 \%$ with a width of $8 \%$. The second Gaussian peak corresponds to the data within the $300-450 \mathrm{hPa}$ range, and the first one to the remaining data. The exact cause of the $5 \%$ difference in the $300-450 \mathrm{hPa}$ range is currently unknown. The difference in the absorption cell pressures between the two instruments was greatest in this pressure range and was about $5 \%$, and thus potentially may be the cause of the discrepancy. As mentioned above, the NOAA- 2 instrument has a redundant absorption cell pressure sensor. The NOAA-1 also has a backup pressure sensor. These backup sensors indi-
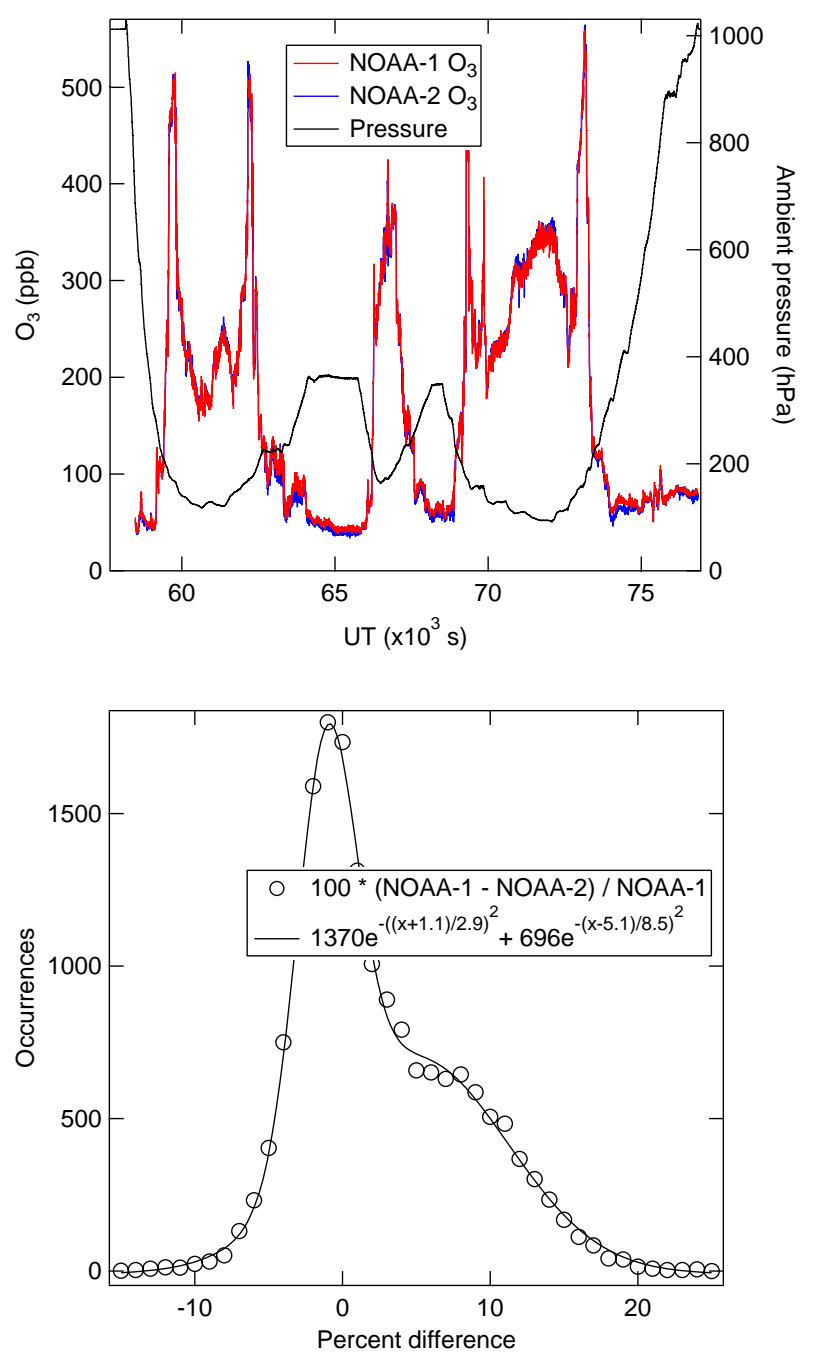

Fig. 9. In-flight intercomparison between the NOAA-1 $\mathrm{O}_{3}$ and NOAA-2 $\mathrm{O}_{3}$ instruments while operating onboard the NASA WB57F high altitude research aircraft on 11 April 2011 in Houston, TX. Top panel: time series of $\mathrm{O}_{3}$ mixing ratio data over the approximately the 5-h flight along with ambient pressure. The NOAA- $2 \mathrm{O}_{3}$ data points are averaged to $1 \mathrm{~s}$ to match the time resolution of the NOAA-1 $\mathrm{O}_{3}$ instrument. Bottom panel: probability distribution of the percent difference between NOAA- $1 \mathrm{O}_{3}$ and NOAA-2 $\mathrm{O}_{3}(100$ * (NOAA-1-NOAA-2) / NOAA-1) with a double-Gaussian fit.

cate that both primary sensors worked appropriately in flight. The results of the laboratory tests shown in Fig. 8 exclude the possibility of nonlinearity of pressure sensors causing the problem. One possible explanation is that the NOAA-2 pressure readings had a flow-induced high bias under flight conditions (e.g. Bernoulli effect) in this pressure range. As shown in Fig. 1, the pressure ports of NOAA-2 are located at the entrances of the absorption cells, where the flow may be most unstable and affected by the inlet-induce flow instability. The pressure sampling error may also help explain the $1 \%$ bias in the laboratory intercomparisons. The larger 
disagreement shown in Fig. 9 suggests that the accuracy of NOAA-2 is degraded to about $5 \%$ in the $300-450 \mathrm{hPa}$ range.

The NOAA-2 $\mathrm{O}_{3}$ data shown in Fig. 9 are 2-point averages, matching the 1-s data rate of the NOAA-1 $\mathrm{O}_{3}$. The intercomparison of precisions is not particularly meaningful due to different inlet configurations. As it is, the NOAA- $2 \mathrm{O}_{3}$ has a slightly better precision with the 2-point average except for occasional large noise spikes (see, e.g. spikes at $71000 \mathrm{~s}$ in Fig. 9) likely due to air flow instability in front of the inlet.

\section{Conclusions}

A new in situ instrument for atmospheric $\mathrm{O}_{3}$ mixing ratio measurements, NOAA-2 $\mathrm{O}_{3}$, was developed and tested in the laboratory and field. The instrument builds upon the UV-absorption technique used by the long-standing NOAA$1 \mathrm{O}_{3}$ instrument, which has flown hundreds of flights in the UT/LS. The NOAA- $2 \mathrm{O}_{3}$ instrument departs from earlier designs by employing polarized UV beams in the absorption cells in order to fold the optical path, which leads to a reduction in the physical cell length required for a given precision. A capillary $\mathrm{Hg}$ lamp was used to increase the available UV intensity. Laboratory tests with an $\mathrm{O}_{3}$ primary standard instrument confirm an accuracy of better than $2 \%$. Flight tests on the NASA WB-57F and Global Hawk UAS platforms showed that laboratory precision and accuracy are maintained in flight. In comparison to the NOAA-1 $\mathrm{O}_{3}$ instrument, the NOAA-2 $\mathrm{O}_{3}$ instrument has an improved sampling rate $(\times 2)$, a better intrinsic precision (by $25 \%$ ), reduced weight (by $30 \%$ ) and reduced payload volume (by $43 \%$ ), while maintaining a similar accuracy $(< \pm 3 \%$ excluding operation in the $300-450 \mathrm{hPa}$ range, where the accuracy may be degraded to about $5 \%$ ) and power consumption. The sampling rate of $2 \mathrm{~Hz}$ of the NOAA-2 $\mathrm{O}_{3}$ corresponds to a horizontal resolution of $100-200 \mathrm{~m}$ and a vertical resolution of $5 \mathrm{~m}$ or less, respectively, at typical research speeds. These features represent a substantial improvement in the feasibility and desirability of integrating the NOAA- $2 \mathrm{O}_{3}$ instrument on board UAS platforms, which generally have less payload capacity, as well as on manned aircraft platforms.

Acknowledgements. This research was supported by the NOAA Atmospheric Composition and Climate Program, the NASA Radiation Sciences Program, and the NASA Upper Atmosphere Research Program. We thank K. K. Kelly for insightful discussions.

Edited by: R. Volkamer

\section{References}

Aimedieu, P. and Barat, J.: Instrument to measure stratospheric ozone with high resolution, Rev. Sci. Instrum., 52, 432-437, 1981.

Ashmore, M. R.: Assessing the future global impacts of ozone on vegetation, Plant Cell Environ., 28, 949-964, 2005.

Barnes, J. and Mauersberger, K.: Temperature Dependence of the Ozone Absorption Cross Section at the 253.7-nm Mercury Line, J. Geophys. Res., 92, 14861-14864, 1987.

Bognar, J. A. and Birks, J. W.: Miniaturized Ultraviolet Ozonesonde for Atmospheric Measurements, Anal. Chem., 68, 3059-3062 1996.

Booker, H. G. and Gordon, W. E.: Outline of a theory of radio scattering in the troposphere, J. Geophys. Res., 55, 241-246, 1950.

Bowman, L. D. and Horak, R. F.: "A Continuous Ultraviolet Absorption Ozone Photometer", in: Air Quality Instrumentation, Vol. 2, edited by: Scales, J. W., Instrument Society of America, Research Triangle Park, NC, 1974.

Brenninkmeijer, C. A. M., Crutzen, P., Boumard, F., Dauer, T., Dix, B., Ebinghaus, R., Filippi, D., Fischer, H., Franke, H., Frieß, U., Heintzenberg, J., Helleis, F., Hermann, M., Kock, H. H., Koeppel, C., Lelieveld, J., Leuenberger, M., Martinsson, B. G., Miemczyk, S., Moret, H. P., Nguyen, H. N., Nyfeler, P., Oram, D., O’Sullivan, D., Penkett, S., Platt, U., Pupek, M., Ramonet, M., Randa, B., Reichelt, M., Rhee, T. S., Rohwer, J., Rosenfeld, K., Scharffe, D., Schlager, H., Schumann, U., Slemr, F., Sprung, D., Stock, P., Thaler, R., Valentino, F., van Velthoven, P., Waibel, A., Wandel, A., Waschitschek, K., Wiedensohler, A., Xueref-Remy, I., Zahn, A., Zech, U., and Ziereis, H.: Civil Aircraft for the regular investigation of the atmosphere based on an instrumented container: The new CARIBIC system, Atmos. Chem. Phys., 7, 4953-4976, doi:10.5194/acp-7-4953-2007, 2007.

Brewer, A. W. and Milford J. R.: The Oxford-Kew ozone sonde, Proc. R. Soc. London, Ser. A, 256, 470-495, 1960.

Gao, R. S., McLaughlin, R. J., Schein, M. E., Neuman, J. A., Ciciora, S. J., Holecek, J. C., and Fahey, D. W.: Computercontrolled Teflon flow control valve, Rev. Sci. Instrum., 70, 4732, doi:10.1063/1.1150137, 1999.

Kalnajs, L. E. and Avallone, L. M.: A Novel Lightweight Low-Power Dual-Beam Ozone Photometer Utilizing SolidState Optoelectronics, J. Atmos. Ocean. Technol., 27, 869, doi:10.1175/2009JTECHA1362.1, 2010.

Kleindienst, T. E., Hudgens, E. E., Smith, D. F., McElroy, F. F., and Bufalini, J. J.: Comparison of chemiluminescence and ultraviolet ozone monitor responses in the presence of humidity and photochemical pollutants, J. Air Waste Manage. Assoc., 43, 213-222, 1993.

Komhyr, W. D.: Electrochemical concentration cells for gas analysis, Ann. Geophys., 25, 203-210, 1969.

Kort, E. A., Wofsy, S. C., Daube, B. C., Diao, M., Elkins, J. W., Gao, R. S., Hintsa, E. J., Hurst, D. F., Jimenez, R., Moore, F. L., Spackman, J. R., and Zondlo, M. A.: Atmospheric observations of high latitude Arctic Ocean methane emissions up to $82^{\circ}$ north, Nat. Geosci., 5, 318-321, doi:10.1038/ngeo1452, 2012.

Lovejoy, S., Tuck, A. F., Hovde, S. J., and Schertzer, D.: Is isotropical turbulence relevant in the atmosphere?, Geophys. Res. Lett., 34, L15802, doi:10.1029/2007GL029359, 2007.

Maier, E. J., Aikin, A. C., and Ainsworth, J. E.: Stratospheric nitric oxide and ozone measurements using photoionization mass 
spectrometry and UV absorption, Geophys. Res. Lett. , 5, 37-40, 1978.

Mao, H., Talbot, R., Troop, D., Johnson, R., Businger, S., and Thompson, A. M.: Smart balloon observations over the North Atlantic: $\mathrm{O}_{3}$ data analysis and modeling, J. Geophys. Res., 111, D23S56, doi:10.1029/2005JD006507, 2006.

Meyer, C. P., Elsworth, C. M., and Galbally, I. E.: Water vapor interference in the measurement of ozone in ambient air by ultraviolet absorption, Rev. Sci. Instrum., 62, 223, doi:10.1063/1.1142311, 1991.

Mudway, I. S. and Kelly, F. J.: Ozone and the lung: a sensitive issue, Molecular aspects of medicine, 21, 1-48, 2000.

Munick, R. J.: Turbulent backscatter of light, J. Opt. Soc. Am., 55, 893, doi:10.1364/JOSA.55.000893, 1965.

Price, H. U., Jaffe, D. A., Doskey, P. V., McKendry, I., and Anderson, T. L.: Vertical profiles of $\mathrm{O}_{3}$, aerosols, $\mathrm{CO}$ and NMHCs in the Northeast Pacific during the TRACE-P and ACE-ASIA experiments, J. Geophys. Res., 108, 8799, doi:10.1029/2002JD002930, 2003.

Proffitt, M. H. and McLaughlin, R. J.: Fast-response dual-beam UVabsorption ozone photometer suitable for use on stratospheric balloons, Rev. Sci. Instrum., 54, 1719-1728, 1983.

Regener, V. H.: Measurement of Atmospheric Ozone with the Chemiluminescent Method, J. Geophys. Res., 69, 3795-3800, 1964.

Ridley, B. A., Grahek, F. E., and Walega, J. G.: A Small HighSensitivity, Medium-Response Ozone Detector Suitable for Measurements from Light Aircraft, J. Atmos. Ocean. Technol., 9, 142-148, 1992.
Ross, M. N., Toohey, D. W., Rawlins, W. T., Richard, E. C., Kelly, K. K., Tuck, A. F., Proffitt, M. H., Hagen, D. E., Hopkins, A. R., Whitefield, P. D., Benbrook, J. R., and Sheldon, W. R.: Observation of stratospheric ozone depletion associated with Delta II rocket emissions, Geophys. Res. Lett., 27, 2209-2212, doi:10.1029/1999GL011159, 2000.

Sander, S. P., Abbatt, J., Barker, J. R., Burkholder, J. B., Friedl, R. R., Golden, D. M., Huie, R. E., Kolb, C. E., Kurylo, M. J., Moortgat, G. K., Orkin, V. L., and Wine, P. H.: Chemical Kinetics and Photochemical Data for Use in Atmospheric Studies, Evaluation No. 17, JPL Publication 10-6, Jet Propulsion Laboratory, Pasadena, available at: http://jpldataeval.jpl.nasa.gov, 2011.

Veres, A. H., Sarlós, F., Varga, A., Szabó, G., Bozóki, Z., Motika, G., and Gyapjas, J.: Nd:YAG Laser-Based Photoacoustic Detection of Ozone: Comparison of Pulsed and Quasicontinuous Wave Operation and Field Tests, Spectrosc. Lett., 38, 377-388, 2005.

Washenfelder, R. A., Wagner, N. L., Dubé, W. P., and Brown, S. S.: Measurement of Atmospheric Ozone by Cavity Ring-down Spectroscopy, Environ. Sci. Technol., 45, 2938, doi:10.1021/es103340u, 2011.

Wilson, K. L. and Birks, J. W.: Mechanism and Elimination of a Water Vapor Interference in the Measurement of Ozone by UV Absorbance, Environ. Sci. Technol., 40, 6361-6367, 2006.

Zucco, M., Curci, S., Castrofino, G., and Sassi, M. P.: A comprehensive analysis of the uncertainty of a commercial ozone photometer, Meas. Sci. Technol., 14, 1683-1689, 2003. 